\begin{tabular}{|l|r|r|}
\hline & $\begin{array}{r}\text { EXPERIMENTAL DEVICE TO EVALUATE MINERAL TRAPPING IN } \\
\text { SANDSTONES AS A MEANS OF SUPERCRITICAL CO2 (scCO2) STORAGE }\end{array}$ & $\begin{array}{r}\text { ENVIRONMENTAL } \\
\text { ENGINEERING AND } \\
\text { TECHNOLOGY }\end{array}$ \\
Ingeniería e Industria & L M Valle-Falcones, C Grima-Olmedo, R Rodríguez-Pons, et al. & Air pollution control \\
\hline COLLABORATION
\end{tabular}

\title{
EXPERIMENTAL DEVICE TO EVALUATE MINERAL TRAPPING IN SANDSTONES AS A MEANS OF SUPERCRITICAL CO2 (scCO2) STORAGE
}

Laura María Valle-Falcones ${ }^{1 *}$, Carlos Grima-Olmedo ${ }^{2}$, Ramón Rodríguez-Pons ${ }^{3}$, Carlos Llopis-Albert ${ }^{4}$

1-3 Dr.la Ingeniero de Minas. Escuela Técnica Superior de Ingenieros de Minas y Energía. Departamento Ingeniería Geológica y Minera. Universidad Politécnica de Madrid; c/ Ríos Rosas 23, 28003 Madrid. “Tfno: 91 0676499. lauramaria.valle@upm.es ${ }^{4}$ Dr. Ingeniero Industrial. Centro de Investigación en Ingeniería Mecánica. Universitat Politècnica de València; cl Camí de Vera $s / n, 46022$ Valencia

Received: 05/apr/2019 - Revising: 08/abr/2019 - Accepted: 27/jun/2019 - DOl: http://dx.doi.org/10.6036/9202

\section{ABSTRACT:}

Carbon dioxide is the main Greenhouse Gas (GHG) due to its abundance in the atmosphere. $\mathrm{CO}_{2}$ capture and storage (CCS) technologies contribute to mitigate the effects of climate change by reducing their emissions. This requires appropriate geological environments such as deep saline aquifers with great potential on an industrial scale in Spain. They must have appropriate characteristics to ensure the tightness of $\mathrm{CO}_{2}$ and the technical viability of the injection process. The capacity of the storage is conditioned by the trap mechanisms that take place in depth. In this work, the static configuration of the ATAP (High TemperatureHigh Pressure) test device has been developed to reproduce the mineralization trap mechanism or mineral sequestration by applying it to a sandstone aquifer for supercritical $\mathrm{CO}_{2}$ storage $\left(\mathrm{SCCO}_{2}\right)$. The equipment allows to observe the changes produced in a rock sample after it has been saturated with the fluids existing in the store $\left(\right.$ brine and $\left.\mathrm{SCCO}_{2}\right)$, under the pressure and temperature conditions characteristic of storage (up to $120^{\circ} \mathrm{C}$ and 500 bar). To verify these changes, the technique of computed axial tomography and He pycnometry were used. The variations of porosity produced in the storage rock are compared with those obtained in studies of $\mathrm{SCCO}_{2}$ saturation by injection and in reactor carried out by other authors.

Keywords: Mineral trapping, deep saline aquifer, sandstone storage, supercritical $\mathrm{CO}_{2}$, high pressure and temperature equipment

\section{Definitions and terms}

ATAP Experimental device-high temperature-high pressure

Artifact Distortion of the radiological image

CCS Carbon capture and storage

Completation Cementation works, among others, carried out in producing wells or oil / gas injectors

DICOM Digital Imaging and Communication on Medicine

$X R D \quad X$-ray diffraction

FOV Field Of View

$\mathrm{SCCO}_{2} \quad \mathrm{CO}_{2}$ in supercritical state

SEM Scanning Electron Microscopy

SSQD Slow Suction Quick Delivery

Sw Brine saturation

$S w_{(100 \%)} \quad$ Brine saturation at $100 \%$

Swi Irreducible brine saturation

CT Computerized Tomography

Vp Pore Volume

W Brine 


\begin{tabular}{|l|r|r|}
\hline & $\begin{array}{r}\text { EXPERIMENTAL DEVICE TO EVALUATE MINERAL TRAPPING IN } \\
\text { SANDSTONES AS A MEANS OF SUPERCRITICAL CO2 (scCO2) STORAGE }\end{array}$ & $\begin{array}{r}\text { ENVIRONMENTAL } \\
\text { ENGINEERING AND } \\
\text { TECHNOLOGY }\end{array}$ \\
Ingeniería e Industria & L M Valle-Falcones, C Grima-Olmedo, R Rodríguez-Pons, et al. & Air pollution control \\
\hline COLLABORATION
\end{tabular}

\section{1.- INTRODUCTION}

Carbon capture and storage technologies (CCS) are presented as an option that could be viable to mitigate the greenhouse gas emissions more abundant in the atmosphere, constituting an alternative to fight against the climate change already proven [1]. The last stage addressed by these technologies is the geological storage of $\mathrm{CO}_{2}$, being necessary to find suitable geological environments to ensure its success. Possible geological structures are the depleted hydrocarbon reservoirs, the underground coal layers and the deep saline aquifers [2], being this last option the one with most potential at industrial scale in Spain. Due to the need to find geological storages that guarantee the technical viability of the injection process and gas tightness [3], it is necessary to develop technologies capable of facing up these challenges associated with CCS projects.

The underground petrophysical and geomechanical properties have influence in the selection of a deep saline aquifer for $\mathrm{CO}_{2}$ storage, also the scope of the trap mechanisms developed over time determine the capacity of the storage and the technical feasibility of the injection process. In addition, the tightness of the $\mathrm{CO}_{2}$ storage in the long term must be guaranteed at all times. The trap mechanisms for $\mathrm{CO}_{2}$ that can be developed in a deep geological storage were defined in 2005 by the Intergovernmental Panel on Climate Change (IPCC) [4], the times of action of each one of them has been collected in a general way in Fig. 1, during and after the injection process.

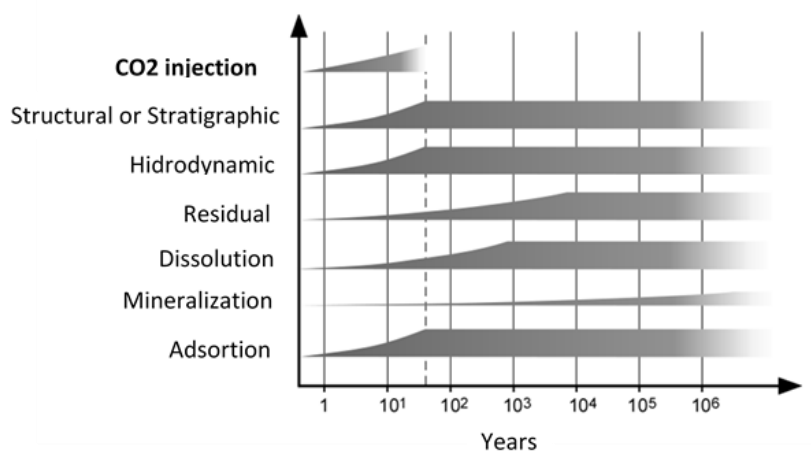

Figure 1. Estimated time of action for the $\mathrm{CO}_{2}$ trap mechanisms. Modified from IPCC 2005.

The trap mechanism of mineralization or mineral sequestration is based on the chemical reactions that are generated between the minerals of the storage rock and the $\mathrm{CO}_{2} /$ brine mixture. The mineral dissolution produces new species that fix the $\mathrm{CO}_{2}$ and modify the porosity and permeability of the storage, altering the $\mathrm{pH}$ of the mixture $\mathrm{CO}_{2}$-brinestorage rock. While mineral sequestration increases with time, its speed of action is conditioned by the particle size of the storage rock, and by the temperature and pressure of $\mathrm{CO}_{2}$ injection.

The need to increase the temperature represents a high energy consumption that can be avoided by the use of bacteria and fungi [5]. These produce the dissolution of organic acids creating protons that attack the mineral surface by the oxygenated parts, making the metal-oxygen barrier weaker, accelerating the dissolution of the magnesium silicates.

Seifritz [6] proposed in 1990 to apply carbonation reactions for the $\mathrm{CO}_{2}$ storage of, being the first studies developed at Los Alamos National Laboratory (LANL) between 1995 and 1997 [7]. The aqueous carbonation consists on the dissolution of the $\mathrm{CO}_{2}$ in the brine, which resulted moderately acidic. Subsequently, the $\mathrm{Ca} / \mathrm{Mg}$ lixiviation occurs, ultimately precipitating the carbonates. The effectiveness of the mineral carbonation process is highly influenced by the type of storage rock (its mineralogy) and the methods or characteristics of the injection. Mineral carbonation could be improved if fully dissolved $\mathrm{CO}_{2}$ is injected into water and/or if it is injected into silicates rich in divalent metal cations, such as basaltic and ultramafic rocks.

The mineral carbonation produced by $\mathrm{CO}_{2}$ injected is different in extrusive rocks (volcanic basalt type) or in sedimentary rocks, being in the latter case a slower process $[8,9]$. The CarbFix project $[10,11]$ was developed with the objective of optimizing the technological development costs for in-situ mineral carbonation in basalts (mostly tolelic with Olivino). The injection zone rocks located south of the Hellisheidi geothermal plant (southwest of Iceland), have an ultrabasic to basaltic composition (with $45-49 \% \mathrm{SiO}_{2}$ ) with vitreous to crystalline structures. In the pilot phase, 175 tons of $\mathrm{CO}_{2}$ were injected, previously dissolved in the brine, where the analysis of nine core feet confirmed that between $80-90 \%$ of $\mathrm{CO}_{2}$ had produced carbonation phenomena in the rock in less than a year. 


\begin{tabular}{|l|r|r|}
\hline & $\begin{array}{r}\text { EXPERIMENTAL DEVICE TO EVALUATE MINERAL TRAPPING IN } \\
\text { SANDSTONES AS A MEANS OF SUPERCRITICAL CO2 (scCO2) STORAGE }\end{array}$ & $\begin{array}{r}\text { ENVIRONMENTAL } \\
\text { ENGINEERING AND } \\
\text { TECHNOLOGY }\end{array}$ \\
Ingeniería e Industria & L M Valle-Falcones, C Grima-Olmedo, R Rodríguez-Pons, et al. & Air pollution control \\
\hline COLLABORATION
\end{tabular}

In this work, the static configuration of a prototype at laboratory scale (ATAP) has been developed for the study of the mineralization trap mechanism or mineral sequestration produced in a sandstone aquifer for $\mathrm{CO}_{2}$ storage. The equipment allows to observe the changes, reactions and precipitations produced in a rock sample, with the fluids present in the storage, in the real conditions of pressure and temperature characteristics of the storage. The variations suffered in the storage rock can be verified through complementary studies of X-Ray Diffraction, $\mathrm{pH}$ measurements, porosity and permeability measurements, or computed tomography with the sample located in the injection cell.

\section{2.- MATERIALS AND METHODS}

For the study of the trap mechanisms and the technical feasibility of $\mathrm{CO}_{2}$ injection in a deep geological storage, a test equipment, ATAP (High Temperature-High Pressure), has been designed with the capacity to reproduce the actual storage conditions of up to $120^{\circ} \mathrm{C}$ and 500 bar. Through its dynamic configuration, studies have been made of physical $\mathrm{CO}_{2}$ trap mechanisms developed in sandstone aquifers [12], phenomena of degradation in cements for the completion of injection wells [13] and improvement of injectivity in the storage [14]. For the analysis of the long-term $\mathrm{CO}_{2}$ seal carried out in this work, it has been necessary to develop a static configuration of the ATAP device (Fig. 2) that allows analyzing the chemical trap mechanism of mineralization or mineral sequestration.

The injection of $\mathrm{CO}_{2}$ /brine corrosive mixtures at high temperatures and pressures requires the use of Hastelloy-type materials with resistances superior to stainless steel. In addition, the use of the CT (Computerized Axial Tomography) technique to visualize the changes produced in the sample under study, maintaining the test pressure and temperature, requires a radiolucent material that prevents the generation of artificial images. This material is a carbon coating in the area of the injection cell where the sample is located that allows the analysis of porosity, saturation, fluid displacement, homogeneities and heterogeneities of the samples, as well as the changes produced by mineralization processes.
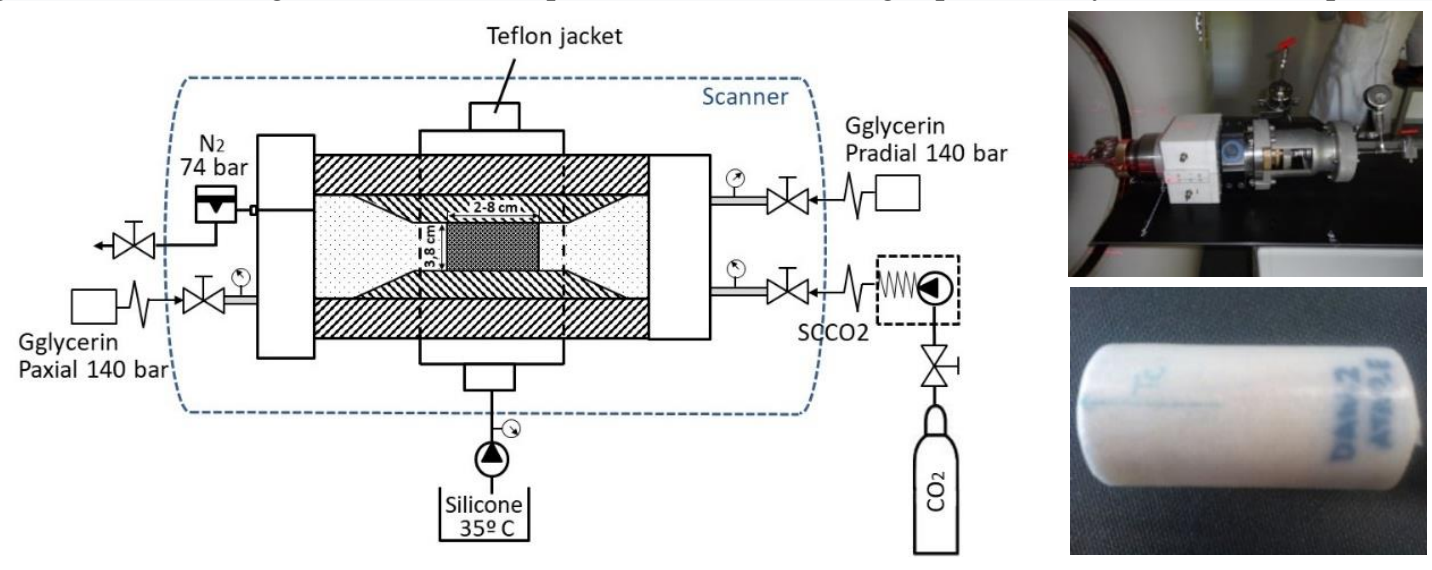

Figure 2. Diagram of the static configuration of the ATAP device. Cell and sample with heat-shrinkable plastic

The rock sample is located inside the body of the cell with a diameter of $3.8 \mathrm{~cm}$ and a length that can vary between 2 and $8 \mathrm{~cm}$, allowing the coupling of shorter samples using adapters in the pistons that close the central body. For this study, three samples of sandstone of the same formation, with a length of $6.5 \mathrm{~cm}, 6.8 \mathrm{~cm}$ and $6.9 \mathrm{~cm}$ respectively, have been tested which have been covered with a thermo-shrinkable plastic to prevent the diffusion of the $\mathrm{CO}_{2}$ through the Viton jacket.

The tested rock is subjected to a radial confining pressure by the pressure increase applied to the glycerin located in the cavity between the Viton jacket that surrounds the sample and the walls of the cell. By the subsequent coupling of the cell, where glycerin is also located, the axial confinement to the sample is provided. In this way, pressure gauges and safety valves are used to control the tri-axial confinement pressure (140 bar) (radial + axial) of the rock, similar to that which would be subjected in a deep saline aquifer.

In order to maintain the constant temperature of the sample, the cell is surrounded by a radiolucent Teflon jacket that allows images without artifacts to be obtained inside a scanner, being able to analyze the changes produced in the rock during the test. The temperature of the jacket is kept constant at $35^{\circ} \mathrm{C}$ by the circulation of the silicone oil pumped, previously heated with a resistance in an external tank. 


\begin{tabular}{|l|l|}
\hline & $\begin{array}{c}\text { EXPERIMENTAL DEVICE TO EVALUATE MINERAL TRAPPING IN } \\
\text { SANDSTONES AS A MEANS OF SUPERCRITICAL CO2 (scCO2) STORAGE }\end{array}$ \\
Ingeniería e Industria & $\begin{array}{r}\text { ENVIRONMENTAL } \\
\text { ENGINEERING AND } \\
\text { TECHNOLOGY } \\
\text { Air pollution control }\end{array}$ \\
\hline COLLABORATION
\end{tabular}

The injection/recovery of one or two fluids can be done independently or mixed before crossing the sample thanks the distribution spiral located on the surface of the two pistons that close the cell, thus avoiding its stratified entry. In this static ATAP configuration, one of the two piston inlets for fluid injection is closed while the other is used to inject first brine and then supercritical $\mathrm{CO}_{2}\left(\mathrm{SCCO}_{2}\right)$. In this injection line there is a valve and a pressure gauge at the entrance of the cell that allows to keep watertight the volume of fluid that saturates the sample during the test at constant pressure.

By means of a back pressure device, with a valve that closes the production of fluids at the outlet, it is possible to inject $\mathrm{CO}_{2}$ into the sample in the supercritical state $\left(\mathrm{SCCO}_{2}\right)$, maintaining a pressure setting of the outlet pressure gauge at 74.5 bar, which is transmitted to the entire fluid injection system. By opening/closing the valve in the filling line with $\mathrm{N}_{2}$, it is possible to vary the pressure of that backpressure equipment to the desired one in the test.

The continuous injection of fluids is carried out separately, on the one hand the brine with a high precision ISCO series$\mathrm{D}$ pump at a flow rate (up to $107 \mathrm{ml} / \mathrm{min}$ ) or constant pressure (up to $517.1 \mathrm{bar}$ ). On the other hand, the liquid $\mathrm{CO}_{2}$ from the bottle by means of a JASCO PU-2080 generator with cooling of its heads for the thermal control below $-4^{\circ} \mathrm{C}$, is pumped in supercritical state avoiding the phase change by decompression when entering the pump. The SSQD pump system provides flow stability (free of pulses) achieving a flow rate of up to $10 \mathrm{ml} / \mathrm{min}$ and a maximum pressure of 35 $\mathrm{MPa}$.

The effect of the mineralization trap mechanism is analyzed before and after the injection test using the He pycnometry and the CT techniques (Somatom medical scanner from the Siemens Company). The images obtained from the sample are compared with a base image fixed for a reference situation in both the cell and the scanner table (Fig. 3).
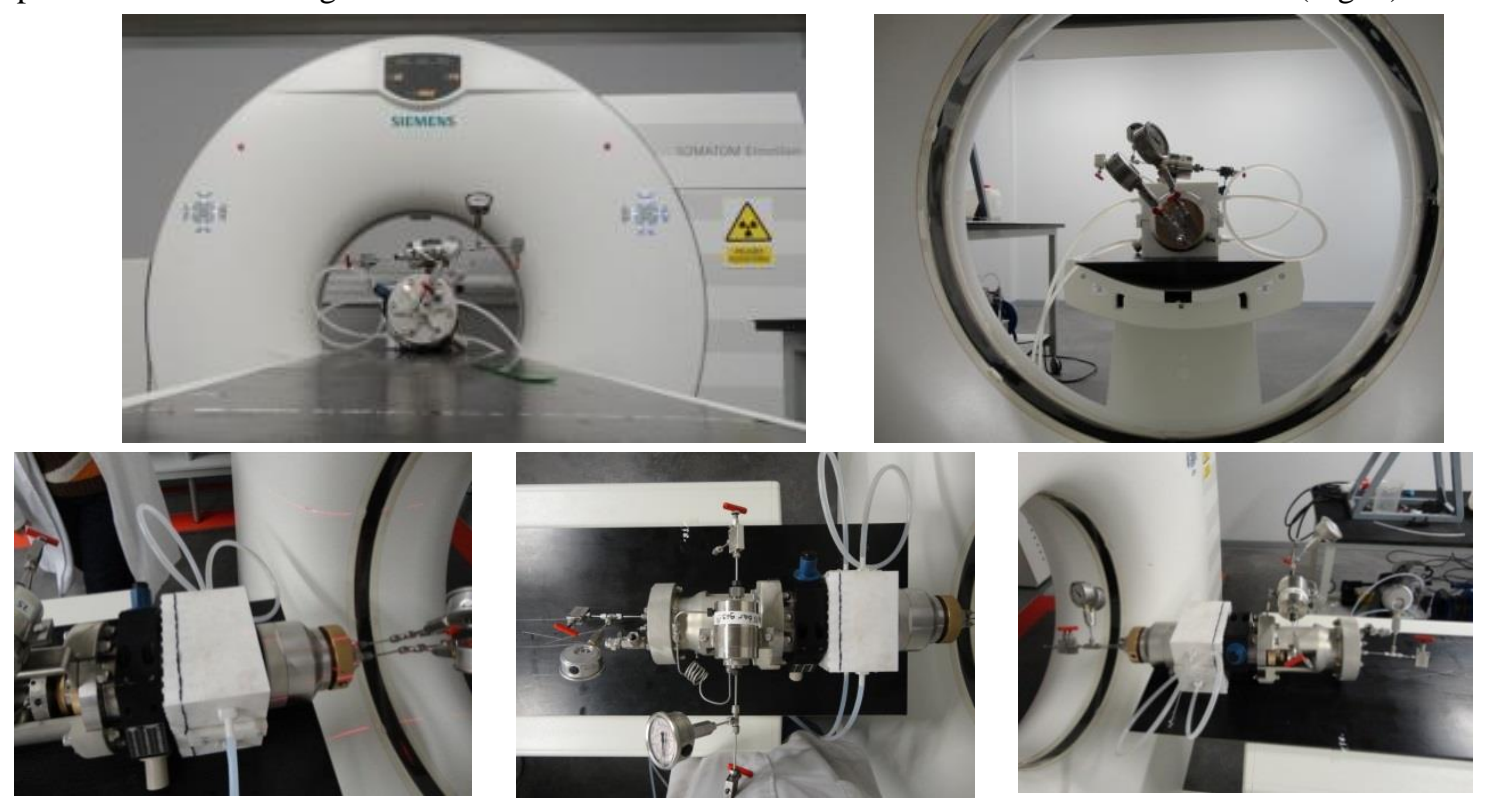

Figure 3. Reference position of the cell on the scanner table.

The brine injection is carried out at a constant flow rate $(1 \mathrm{cc} / \mathrm{min})$ until 20 times the pore volume of the sample is injected, at which time we consider it is $100 \%$ saturated in brine $\mathrm{Sw}(100 \%)$. Once the pressure and temperature conditions have been established inside the cell, with the sample brine saturated and the connection valves closed, the study position is set to obtain the sequence of CT1 images of the sample during the test by means of the scanner (Fig.4). 


\begin{tabular}{|l|r|r|}
\hline & $\begin{array}{r}\text { EXPERIMENTAL DEVICE TO EVALUATE MINERAL TRAPPING IN } \\
\text { SANDSTONES AS A MEANS OF SUPERCRITICAL CO2 (scCO2) STORAGE }\end{array}$ & $\begin{array}{r}\text { ENVIRONMENTAL } \\
\text { ENGINEERING AND } \\
\text { TECHNOLOGY }\end{array}$ \\
Ingeniería e Industria & L M Valle-Falcones, C Grima-Olmedo, R Rodríguez-Pons, et al. & Air pollution control \\
\hline COLLABORATION
\end{tabular}

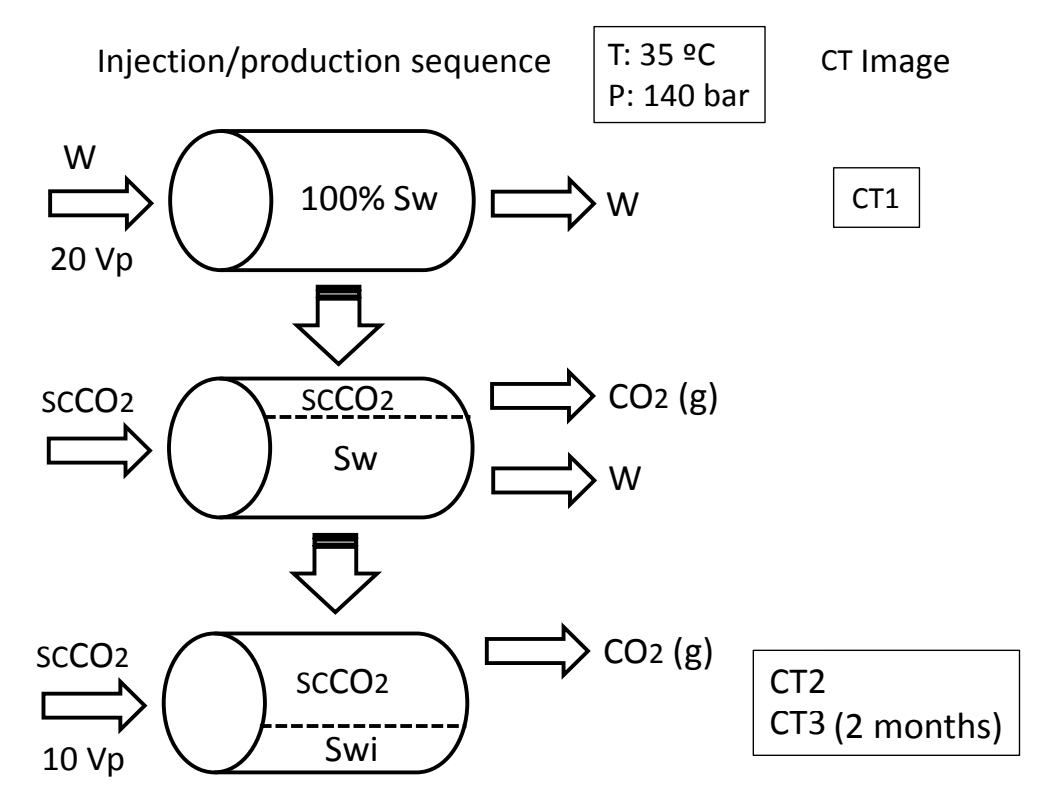

Figure 4. Phases of the injection test and sequence of the computed tomography record CT1-3

The injection of $\mathrm{SCCO}_{2}$ is then carried out at a flow rate of $1 \mathrm{cc} / \mathrm{min}$, obtaining an equivalent volume of injection of 10 times the pore volume $(\mathrm{Vp})$, displacing the brine from the sample inside. The injection continues until no more brine is produced and only $\mathrm{CO}_{2}(\mathrm{~g})$ is recovered at the outlet of the cell. At that time it is considered that the sample is saturated in $\mathrm{SCCO}_{2}$ and in the volume of undisplaced brine that constitutes the irreducible saturation Swi. The injection and production valves of the cell are closed and the second computed tomography image CT2 is obtained (Fig. 4). The cell is kept sealed at constant temperature and confining pressure for two months, during which the mineralization process takes place by reaction of the rock, brine and $\mathrm{SCCO}_{2}$ in the sample (mineralization trap mechanism). A third CT3 computed tomography study was performed with the cell in the study position (Fig. 4).

Once the CT3 study is done, valves are opened and the sample inside the cell is recovered. The sample is placed in an oven and kept at $25^{\circ} \mathrm{C}$ until it is dry, then, its porosity is measured after the test in the He Pycnometry equipment.

\section{3.- RESULTS AND DISCUSSION}

The images obtained with the scanner by means of the field of view (FOV), in the selected window, are compared to observe the possible changes that affect the sample in the different stages of the test. By means of the software with image acquisition, with DICOM standard, the slices are obtained (approximately 107 per study) made in the saturated sample in brine and later in $\mathrm{SCCO}_{2}$, calculating the average intensities in Hounsfield units. The image composed of intensity measurements in gray scale shows variations from white to black that determine the density of the material in the different points crossed by the X-rays. The white correspons to the densest material and the black to the least dense. Through the image treatment program, the maximum intensity measurement is obtained in each of the slices (Fig. 5).

\begin{tabular}{|c|c|c|}
\hline & $\begin{array}{l}\text { Publicaciones DYNA SL -- c) Mazarredo no69 - } 4^{\circ}--48009 \text {-BILBAO (SPAIN) } \\
\text { Tel +34 } 944237566 \text { - www.revistadyna.com - email: dyna@revistadyna.com }\end{array}$ & Pag. $5 / 9$ \\
\hline
\end{tabular}




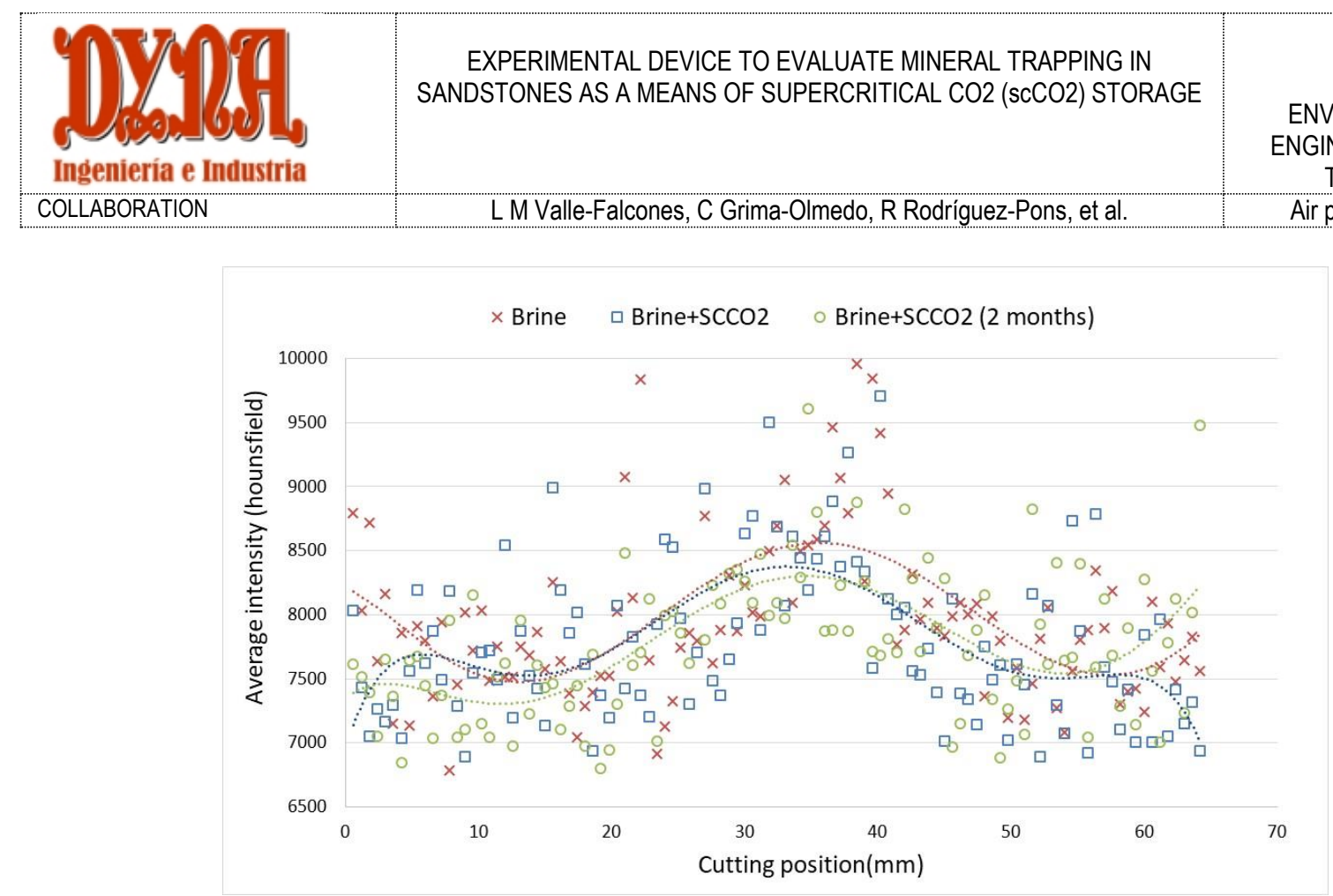

Figure 5. Maximum intensity measurements of each of the slices in each stage

Figure 6 compares the images obtained from the first sample of sandstone (representative of the formation) inside the cell at the pressure and temperature of the storage in four slices at 6,12,18 and $24 \mathrm{~mm}$ distance from the injection surface, saturated in brine (CT1), the sample saturated in $\mathrm{SCCO}_{2}$ and the irreducible volume of brine (CT2), and two months after the sample saturation with $\mathrm{SCCO}_{2}(\mathrm{CT} 3)$. The comparison of the studies carried out in each of the stages and in the positions fixed in the sample is then carried out.

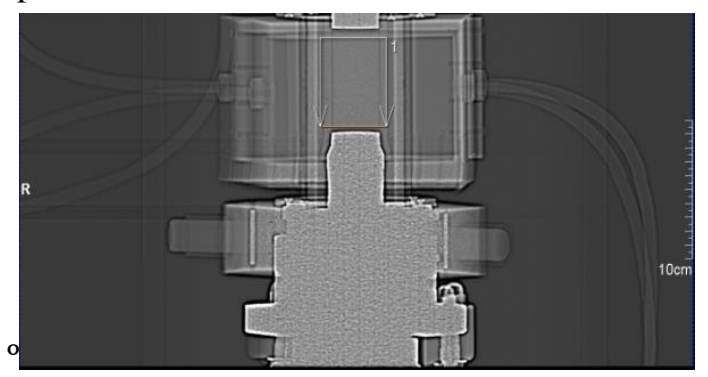

\section{CT1 \\ CT3}

\begin{abstract}
I. Slice $10=6 \mathrm{~mm}$
\end{abstract}

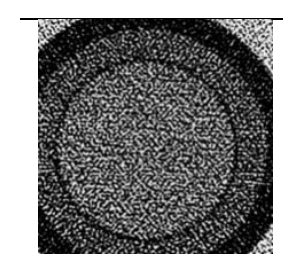

\section{Slice $30=18 \mathrm{~mm}$}

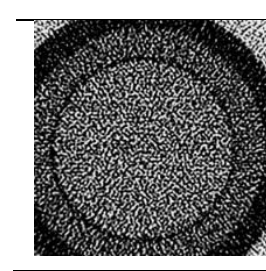

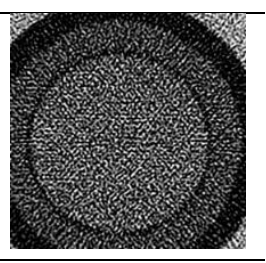

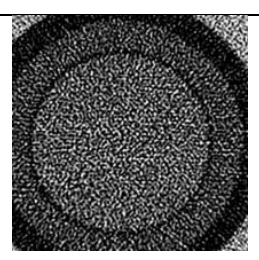

CT1
CT2

II. Slice $20=12 \mathrm{~mm}$
CT3

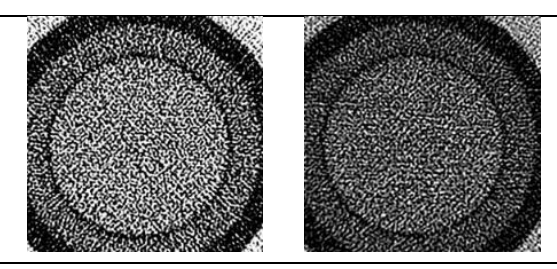

IV. Slice $40=24 \mathrm{~mm}$

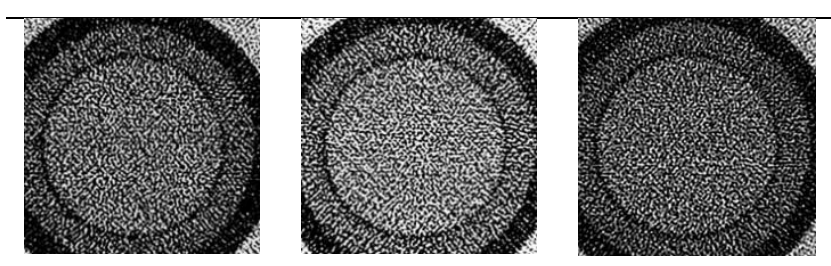

Figure 6. Scanogram of the sample located inside the cell. Images of the scanner in the different stages and study positions 


\begin{tabular}{|l|r|r|}
\hline & $\begin{array}{c}\text { EXPERIMENTAL DEVICE TO EVALUATE MINERAL TRAPPING IN } \\
\text { SANDSTONES AS A MEANS OF SUPERCRITICAL CO2 (scCO2) STORAGE }\end{array}$ \\
Ingeniería e Industria & $\begin{array}{r}\text { ENVIRONMENTAL } \\
\text { ENGINEERING AND } \\
\text { TECHNOLOGY }\end{array}$ \\
\hline COLLABORATION & Air pollution control \\
\hline
\end{tabular}

For the first sample of tested sandstone, no significant qualitative changes are observed as a result of the different injections. This is due to there is not variations of the macro porosity in the images provided of the samples by the CT technique.

After two months of residence of the $\mathrm{SCCO}_{2}$, the cell is opened and the sample is recovered, which, once is dried in an oven, is subjected to a quantitative study with the He Pycnometer, obtaining a total porosity of $10.90 \%$. Table I also shows the porosity results $(9.42 \%$ and $8.85 \%)$ of the other two tests carried out in sandstone samples of the same formation, at $35^{\circ} \mathrm{C}$ of temperature and respective pressures of $140 \mathrm{bar}$ and $75 \mathrm{bar}$.

In another study conducted by Campos et al [15] where a sandstone sample from Utrillas was subjected to the injection of $\mathrm{SCCO}_{2}$ and brine under storage conditions $\left(80 \mathrm{bar}\right.$ and $32^{\circ} \mathrm{C}$ ), a decrease in its porosity was measured with $\mathrm{Hg}$ porosimetry, $15.64 \%$ to $9.70 \%$, similar to that observed in the samples used in our study (Table I). This decrease of the meso porosity due to mineral precipitation leads to a lower storage capacity of the $\mathrm{CO}_{2}$ injected later. Although this contradicts the studies of Berrezueta et al [16], where there is an increase in porosity, this is a phenomenon that depends not only on the mineralogy of the storage and the composition of the brine, but also on the time of $\mathrm{CO}_{2}$ permanence in the aquifer.

\begin{tabular}{|c|c|c|c|c|c|c|c|c|}
\hline \multicolumn{2}{|c|}{ Sample } & \multicolumn{3}{|c|}{ Test } & \multicolumn{3}{|c|}{ Porosity measurement } & \multirow{2}{*}{ Ref. } \\
\hline Rock & Location & Device & P\&T & Duration & Method & Before & After & \\
\hline \multirow{3}{*}{ Sandstone } & \multirow{3}{*}{ Duero Basin } & \multirow{3}{*}{$\begin{array}{l}\text { Injection } \\
\mathrm{SCCO}_{2}-\mathrm{W}\end{array}$} & 140 bar & \multirow{3}{*}{2 months } & \multirow{3}{*}{$\begin{array}{l}\mathrm{He} \\
\text { Pycnometry }\end{array}$} & 16,97 & 10,90 & \multirow{3}{*}{ This work } \\
\hline & & & $35^{\circ} \mathrm{C}$ & & & 14,85 & 9,42 & \\
\hline & & & $\begin{array}{l}75 \text { bar } \\
35^{\circ} \mathrm{C}\end{array}$ & & & 12,53 & 8,85 & \\
\hline Sandstone & Ebro Basin & $\begin{array}{l}\text { Injection } \\
\mathrm{SCCO}_{2}-\mathrm{W}\end{array}$ & $\begin{array}{l}80 \text { bar } \\
32^{\circ} \mathrm{C}\end{array}$ & 2 months & $\begin{array}{l}\mathrm{Hg} \\
\text { Porosimeter }\end{array}$ & 15,64 & 9,70 & $\begin{array}{l}\text { Campos } \\
\text { et al, } 2015\end{array}$ \\
\hline $\begin{array}{l}\text { Feldespar } \\
\text { Sandstone }\end{array}$ & $\begin{array}{l}\text { Guadalquivir } \\
\text { Basin }\end{array}$ & \multirow{2}{*}{$\begin{array}{l}\text { Reactor } \\
\text { with } \\
\mathrm{SCCO}_{2}\end{array}$} & \multirow{2}{*}{$\begin{array}{l}75 \text { bar } \\
35^{\circ} \mathrm{C}\end{array}$} & \multirow{2}{*}{$1000 \mathrm{~h}$} & \multirow{3}{*}{$\begin{array}{l}\text { OpM and } \\
\text { SEM }\end{array}$} & 12,63 & 12,94 & \multirow{3}{*}{$\begin{array}{l}\text { Berrezueta } \\
\text { et al, } 2017\end{array}$} \\
\hline Greywacke & Ebro Basin & & & & & 19,01 & 21,16 & \\
\hline $\begin{array}{l}\text { Quartz- } \\
\text { sandstone }\end{array}$ & Duero Basin & $\begin{array}{l}\text { Reactor } \\
\text { with } \\
\mathrm{SCCO}_{2}-\mathrm{W}\end{array}$ & $\begin{array}{l}75 \text { bar } \\
35^{\circ} \mathrm{C}\end{array}$ & $24 \mathrm{~h}$ & & 9,55 & 11,13 & \\
\hline
\end{tabular}

$\mathrm{SCCO}_{2}$ : supercritical $\mathrm{CO}_{2} ;$ W: brine

OpM: Optical image analysis with thin-section; SEM: scanning electron microscopy

Table I. Comparative results of $\mathrm{SCCO}_{2}$ injection in different types of rock and test conditions

Table I shows the difference in the variation of the porosity according to the methodology used to lead the aquifer sample to the pressure and temperature of the storage conditions. An increase in porosity occurs when performing the tests in the reactor, both with the sample submerged in $\mathrm{SCCO}_{2}$ and in the $\mathrm{SCCO}_{2}$-brine mixture, compared to the decrease produced when the $\mathrm{SCCO}_{2}$-brine mixture is injected into the sample (located inside the triaxial cell). Further complementary and sensitivity studies would be necessary to justify the variation of these results, taking into account the influence of factors such as the mineralogy of the sample, the composition of the brine and the technique used to introduce supercritical $\mathrm{CO}_{2}$ into the rock.

After the $\mathrm{SCCO}_{2}$ injection, its transformation into $\mathrm{CO}_{2}(\mathrm{aq})$ and $\mathrm{HCO}_{3}{ }^{-}$is first produced by dissolving it in the brine, thereby increasing the safety of the store, since no $\mathrm{CO}_{2}$ is found in the free phase. Subsequently, mineral dissolution is caused by varying the $\mathrm{pH}$ of the $\mathrm{SCCO}_{2}$-brine mixture [17]. These processes produce a decrease in system pressure and the consequent separation of $\mathrm{CO}_{2}$ from the aqueous phase as its solubility decreases, creating a $\mathrm{CO}_{2}$-free phase again. All this causes the subsequent mineral precipitation, producing changes in the morphology, porosity and permeability of the porous medium, which then affect the natural biphasic flow of $\mathrm{CO}_{2}$ and the formation water (brine) inside the storage, influencing the storage capacity and security, being necessary to study in each case those variations to know their contribution.

Additional studies could be carried out to obtain the $\mathrm{pH}$ of the effluents, the characterization of the mineralogy and petrography by means of XRD, SEM or optical image analysis $[16,18,19]$, as well as petrophysics with the measure of the variation of the permeability. Likewise, the scope of the study of the characteristic chemical reactions of the 


\begin{tabular}{|l|r|c|}
\hline & $\begin{array}{r}\text { EXPERIMENTAL DEVICE TO EVALUATE MINERAL TRAPPING IN } \\
\text { SANDSTONES AS A MEANS OF SUPERCRITICAL CO2 (scCO2) STORAGE }\end{array}$ & $\begin{array}{r}\text { ENVIRONMENTAL } \\
\text { ENGINEERING AND } \\
\text { TECHNOLOGY } \\
\text { Ingeniería e Industria } \\
\text { COLLABORATION }\end{array} \quad$ Air pollution control \\
\hline
\end{tabular}

mineralization trap mechanism could be broadened based on the geomechanics of the storage and the possible effects on the sealing of $\mathrm{CO}_{2}$ in the aquifer [20].

\section{4.- CONCLUSIONS}

The ATAP equipment in its static configuration has allowed reproducing the chemical trap mechanism of mineralization developed by injecting $\mathrm{CO}_{2}$ into the sample at the pressure and temperature of the deep saline aquifer. The test time of the sample under these conditions allows the study of the chemical reactions that occur between the rock, brine and $\mathrm{SCCO}_{2}$ characteristics of the mineral sequestration.

The studies with CT of the innner part of the sample located in the cell (at the pressure and temperature of the test) make it possible to observe the variations in its mineralogy, and if fracture or cavity phenomena have been generated. It has been found that the variation in the porosity of the tested sandstone sample was not appreciable enough with this technique. Its application is reduced to cases in which significant qualitative changes occur, either by the mineralogy of the storage (basaltic rocks) where the mineralization processes are more urgent in the short term, or by more aggressive chemical reactions due to the composition of the brine.

For the complete study of mineral sequestration developed in underground storage, an assay methodology should be followed where, prior to the injection of the fluids of known composition, the mineralogy and porosity of the samples to be tested are analyzed. It is recommended to use analytical techniques such as the XRD and SEM in the injection surface, which allow to select the areas of interest, and by means of mercury porosimetry to quantify the pore sizes and volumes, as well as their distribution and interconnection.

The nature of the mineralization trap mechanism determines that the time of permanence of the $\mathrm{CO}_{2}$ in the supercritical state in the cell during the test is a function of the mineralogy of the sample, and can be reduced with the use of catalysts that accelerate the chemical reactions. In this case, it is convenient to study the chemical reactions that may develop in the aquifer. It is suggested the possibility of measuring the $\mathrm{pH}$ of the initial and final effluents, after the permanence of the supercritical $\mathrm{CO}_{2}$ in the sample and observe its variation. It would be convenient to analyze the variation of its mineralogy, in the same points prior to the injection, check the variation of its porous structure, and study the chemical composition of the effluents obtained.

The dissolution and mineral precipitation modifiy the porous structure expanding the throat diameters and decreasing the specific surface area of the pores, resulting in lower capillary pressures and changes in relative permeability. As a result, there is an increasing resistance to the flow of brine and a decrease in the mobility of the injected $\mathrm{CO}_{2}$, acting as a self-sealing mechanism, being unfavorable to the migration of $\mathrm{CO}_{2}$ to leakage areas (faults, fractures) or seal. The study with ATAP and the complementary tests of the processes developed in each storage, conditioned by its mineralogy and its specific geology, leads to a more precise knowledge of the storage capacity of the geological formation and of the safety in the sealing of the $\mathrm{CO}_{2}$ in the storage in the long term.

\section{REFERENCES}

[1] Broecker WS. Climate change - CO2 arithmetic. Science, 200. Vol. 315 (5817), 1371-1371. http://dx.doi.org/10.1126/science.1139585

[2] Zhang, D., song, J. 2014. Mechanisms for geological carbon sequestration. Procedia IUTAM 10, 319-327.

[3] Bachu S. Sequestration of $\mathrm{CO} 2$ in geological media in response to climate change: road map for site selection using the transform of the geological space into CO2 space. Energy conversion \& management, 2002 (43) 87-102. http://dx.doi.org/10.1016/S0196-8904(01)00009-7

[4] Metz, B., Davidson, O., Coninck, H.C. et al. 2005. IPCC, 2005: IPCC special Report on Carbon Dioxide Capture and Storage. Prepared by working Group III of the Intergovernmental Panel on Climate Change. Cambridge University Press, Cambridge. United Kingdom and New York, NY, USA-442 pp. ISBN- 13978-0-521-68551-1.

[5] Ah-Hyung AP, Matter J, Chandran K. Microbial and chemical enhancement of in-situ carbon mineralization in geological formation. Final report. Columbia University, December 15, 2. DOE Award Number: DE-FE0002389.

[6] Seifritz W. CO2 Disposal By Means of Silicates. Nature, 1990. Vol. 345, 6275, 486. http://dx.doi.org/10.1038/345486b0

[7] Huijgen WJJ, Comans. Carbon dioxide sequestration by mineral carbonation. Literature Review Update 2003-2004. Energy Research Centre of Netherlands. R.N.J.2003-2004.

[8] Gutknecht, V., Snæbjörnsdóttir, S.Ó., Sigfússon, G., Aradóttir, E.S., Charles, L. Creating a carbon dioxide removal solution by combining rapid mineralization of CO2 with direct air capture. Energy Procedia, 2018. Vol. 146, 129-134.

[9] Xue Z, Mito S, Kitamura K, et al. Case study: trapping mechanisms at the pilot-scale CO2 injection site, Nagaoka, Japan. Energy Proceida 1. 2009, 2057-2062. http://dx.doi.org/10.1016/i.egypro.2009.01.268

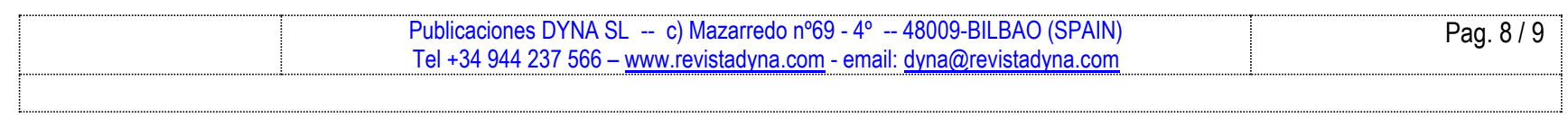




\begin{tabular}{|c|c|c|}
\hline Ingeniería e Industria & $\begin{array}{l}\text { EXPERIMENTAL DEVICE TO EVALUATE MINERAL TRAPPING IN } \\
\text { SANDSTONES AS A MEANS OF SUPERCRITICAL CO2 (scCO2) STORAGE }\end{array}$ & $\begin{array}{r}\text { ENVIRONMENTAL } \\
\text { ENGINEERING AND } \\
\text { TECHNOLOGY }\end{array}$ \\
\hline COLLABORATION & L M Valle-Falcones, C Grima-Olmedo, R Rodríguez-Pons, et al. & Air pollution control \\
\hline
\end{tabular}

[10] Sigurdur Reynir S, Wolff-Boenisch D, Stefansson A. et al. Mineral Sequestration of carbon dioxide in basalt: A pre-injection overview of the CarbFix project. International Journal of Greenhouse Gas Control, 2010. Vol. 4, 3, 537-545. http://dx.doi.org/10.1016/j.ijggc.2009.11.013

[11] Snæbjörnsdóttir, S.Ó., Tómasdóttir, S., Sigfússon, B., et.al. The geology and hydrology of the CarbFix2 site, SW-Iceland. Energy Procedia, 2018. Vol. 146, 146-157.

[12] Valle LM, Rodríguez R, Grima C. et al. Effects of supercritical CO2 injection on sandstones wettability and capillary trapping. International Journal of Greenhouse Gas Control, 2018. Vol. 78, 341-348. http://dx.doi.org/10.1016/j.jiggc.2018.09.005

[13] Estévez E, Valle L, del Barrio D, et al. Cements of improved sealing capacity in CO2 geological storage. Congreso Eurock. Vigo, 2014. http://www.semr.es/wp-content/uploads/2015/06/Boletin7SEMR.pdf

[14] de Dios JC, Delgado MA, Marín JA. et al. Short-term effects of impurities in the $\mathrm{CO} 2$ stream injected into fractured carbonates. International Journal of Greenhouse Gas Control, 2016. Vol 54, 727-736. http://dx.doi.org/10.1016/j.ijggc.2016.08.032

[15] Campos R, Barrios I, Lillo J. Experimental CO2 injection: Study of physical changes in sandstone porous media using Hg porosimetry and 3D network models. Energy Reports, 2015. Vol. 1, 71-79. http://dx.doi.org/10.1016/i.egyr.2015.01.004

[16] Berrezueta E, Domínguez Cuesta MJ, Ordóñez Casado B, et al. Pore space quantification of sedimentary rocks before-after supercritical CO2 interaction by optical image analysis. Energy Procedia, 2017. Vol. 114, 4382-4393. http://dx.doi.org/10.1016/j.egypro.2017.03.1591

[17] Ruina X, Rong L, Jin M, et al. Effect of Mineral Dissolution/Precipitation and CO2 Exsolution on CO2 transport in Geological Carbon Storage. Published as part of the Accounts of Chemical Research special issue "Chemistry of Geologic Carbon Storage". Acc. Chem. Res. 2017, 50, 2056-2066.DOI: 10.1021/acs.accounts.6b00651

[18] Mateos Redondo F, Kovács T, Berrezueta E. Petrographic and petrophysical characterization of detrital reservoir rocks for $\mathrm{CO} 2 \mathrm{Geological}$ Storage (Utrillas and Escucha Sabdstones, Nother Spain). Geosciences, 2018. Vol 8, 7 UNSP 246.http://dx.doi.org/10.3390/geosciences8070246

[19] Berrezueta E, Kovacs T. Application of optical image analysis to the assessment of pore space evolution after $\mathrm{CO} 2$ injection in sandstones. A case study. J. Pet. SCi. Eng. 2017. Vol159, 679-690. http://dx.doi.org/10.1016/i.petrol.2017.08.039

[20] Raza A, Gholami R, Sarmadivaleh M, et al. Integrity analysis of CO2 storage sites concerning geochemical-geomechanical interactions in saline aquifers. Journal of Natural Gas Science and Engineering, 2016. Vol. 36, 224-240. http://dx.doi.org/10.1016/i.jngse.2016.10.016

\section{ACKNOWLEDGEMENTS}

To the Petrophysical Institute Foundation (IPf) for the financial support for the development of the ATAP experimental facility, and to the French Petroleum Institute (IFP) for the training received for the design of the testing device. 